\title{
Transport and Logistics - Interference in Marketing
}

\author{
Oleg Pogila \\ oleg.pogila.97@gmail.com \\ Pavel Topala \\ pavel.topala@gmail.com \\ Alecu Russo State University of Balti, Republic of Moldova \\ Lucretia Mariana Constantinescu \\ maractinescu@gmail.com \\ Valahia University of Targoviste, Romania
}

\begin{abstract}
The product logistics covers all phases of the production cycle from raw material supply to storage in warehouses. Logistics remains a cross - cutting function in closing relationship of the other enterprise functions that making it difficult to specify its place within the organizational structure. Logistics has an important role for the enterprise because about $87 \%$ of the product time is in one place is actually used to move and store it. Logistics aims to involve the integration of flow control in the enterprise strategy. This paper aims some solutions which allow to reduce the logistics costs of the enterprise and may improve the logistics services' performence, also.
\end{abstract}

Key words: auto transport, aerodynamics, economy, Cost; logistics performance.

JEL Code: 033; R40; M21.

\section{Introduction}

Product logistics covers all phases of the production cycle, from raw material supply to storage in ware houses. Support logistics comes from the sale of products and includes after-sales and maintenance.

Logistics remains a cross-cutting function closely related to other functions of the company, making it difficult to specify its place within the undertaking.

Logistics aims to involve the integration of flow control in business strategy and play a key role for the company (about $87 \%$ of the product time is one place) and it is used for its moving and storing (Caraiani, Potecea, 2013).

Transport is particularly important into the logistics infrastructure by the reasons such as: the full cost; downtime of goods during their transport; implication of each flow disruption and the logistics performance is strongly correlated with the "Total quality" services into the production and marketing of the goods (Constantinescu, 2007).

In turn, the transport offer is multiple according: the means which it uses; the communication means which it uses; the size of the undertakings carrying out the transport performance. Choosing the means of transport is therefore strategically part of the overall decision to implement a logistical infrastructure including the number, geographical location, size and types of deposit (Caraiani, Potecea, 2013).

The road goods transport design the „lion's share of the output of the logistic chain whether on its own or in multimodal operations".

According to IRU Resolutions "the transport is a key driver of economic and social progress because it moves goods and people and contributes to the performance of world-wide services. The logistic sector holds about $6,70 \%$ of the world Gross Domestic Production (GDP) with a total value of logistics operations exceeding $10 \%$ of the world trade (IRU, 2005). 
Consequently, the contribution of national and international logistical activities which ensure the mobility of goods on the international market amounts to more than US \$2000 billion.

Freight transport by road is the central part of the supply chain, either considered individually or as a multimodal operation. Worldwide, trucks carry around $80 \%$ of cargo on land routes (fig.1).

Fig. 1. Road transport report for rail transport

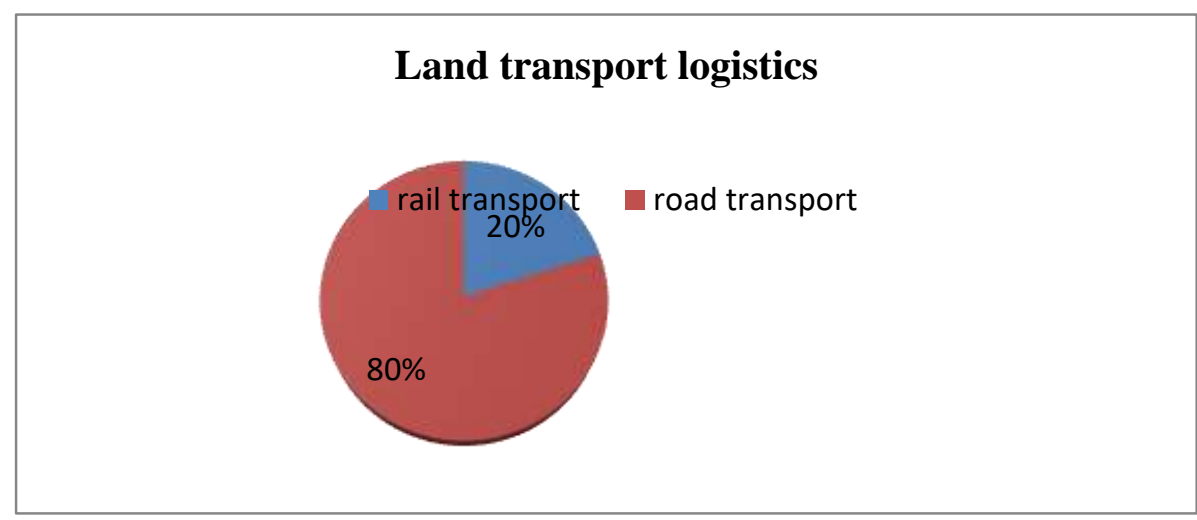

Source: Dantuma, L. M. Y. \& Hawkins R. W. (2001)

During the 2017 year the necessary road transport costs amounted to USD 72.20 billion. It is expected that the global market for transportation management system to increase from USD 78.20 billion in 2017 to USD 202.14 billion by 2022 at a compound annual growth rate of $20.9 \%$ (www.worldbank.org).

Thus, if we admit that transport, whatever its kind, plays an important role in the national and international economy, then the analysis and research of the problem, how expenses could be reduced, is a necessary and current problem.

Any measure facilitating the road transport and it has a beneficial and lasting impact on economic and social progress and the welfare of nations" [according to 3rd source]

And it the fallowing this paper aims the costs arising from the unit carriage of heavy tonnage transport and the way in which they are reduced.

\section{Methods for solving the logistic performance of road transport costs, expenditure. Review for heavy tonnage road transport.}

According to the above data, it can be concluded that the necessary costs are relatively high.

If we compare with other modes of transport, for example the sea, we would notice that the sea requires much lower costs. Instead we must be aware that delivery time is much higher, which in some cases is unacceptable.

The same goes for railway transport, even if the delivery time is not much lower than the road transport time.

Another way of transporting goods is the air transport, in which the delivery time is considerably lower than the road time. Instead, the cost of such transport is much higher than in the cases mentioned above. So, the goods transport by road in balance with the cost of transport and delivery time.

But it doesn't prove that we are unable to optimize it, thus reducing costs for these. With the increase in speed, for example, in the case of long distance journeys on the motorway, the form of the car also influences the fuel consumption: an extra power is used to overcome air resistance, which means an additional amount of fuel is being used. 
Even at the same speeds, which are not very high, the movement of a rationalized machine requires less power and will have less fuel consumption than a low flow motor that may be confirmed by the numerous calculations and experiments.

"CX coefficient" is a parameter that shows resistance to air in a car driving. The drag coefficient is smaller then the air resistance to the movement of the vehicle is smaller.

The result is an increase in the maximum speed, improved vehicle performance and low fuel consumption (https://ustroistvo-avtomobilya.ru/teoriya/soprotivlenie-vozduha-i-rashodtopliva ).

The most important activities within the logistics chain are considered (Caraiani, Potecea, 2013):

- processing - involves receiving and processing the customer's request, cargo distribution planning, the distribution of goods, packing the goods for shipment (on pallets or in containers);

- shipment which involves moving goods from one place to another, or directly to the destination, to an intermediary on the logistics chain;

- storage and/or logistics activities with added value represent an optional intermediate

stage in this process that can contribute to increase the value of goods by means of logistic activities of adding value-represents an optional intermediate stage in this process that can contribute to increase the value of goods by means of logistic activities of adding value.

Fig. 2. The value chain, generically represented for logistics

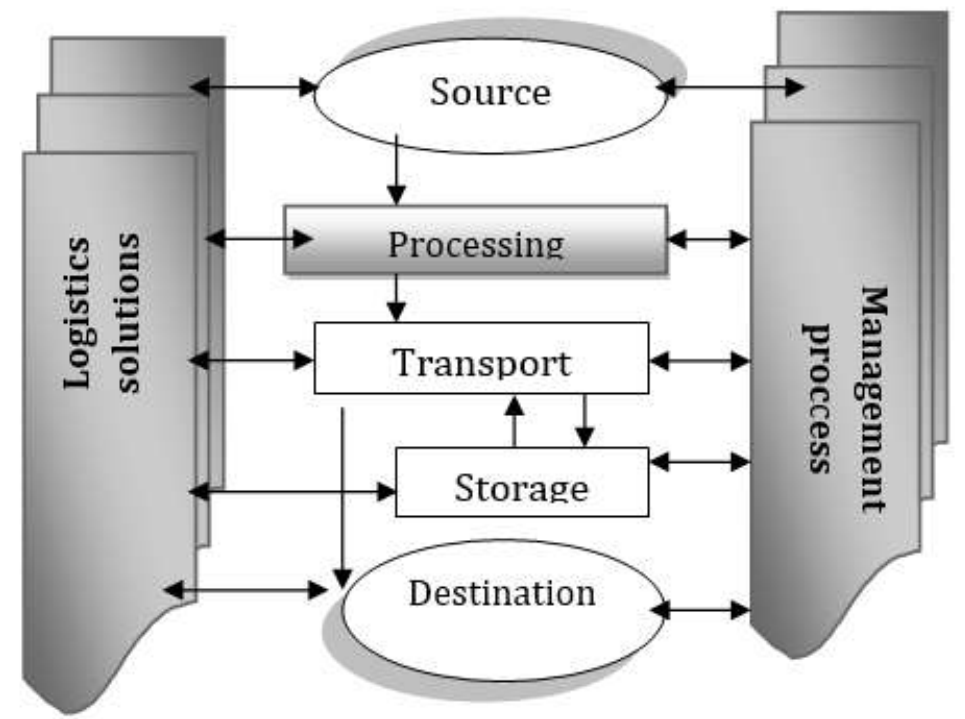

Source: Adaptation by Dantuma M.Y., Hawkins R.W., 2001.

All mentioned stages (fig.2) may have different degrees of contact with the two levels which are vertical in the value chain (the level to a certain degree can relate to any or all of the three basic processes as described above).

The two levels which are located on the vertical are (fig.2):

O management processes - such as tracking and recording capacity;

the logistical solutions which involve the consultancy services which relate to the logistical options available in any or all the levels mentioned above, taking into account the needs of specific customers and product types.

Phases above-mentioned can be considered mainly as activities and functions performed by different actors at transaction leading to value-increasing. In practice, the activities and 
functions can be divided into several specific value added activities. This assertion is particularly true for logistical activities involving planning, management and coordination and, subsequent, many other added value activities that can be generated.

\subsection{General characteristics of the road transport of goods}

Strong domination of road transport use in logistical activities and in the ease of its operation has however their own problems.

There are two groups of problems that can cause difficulty in terms of road transport and restrictions on movement and on car park management. They are included into the travel restriction categories (Caraiani, Potecea, 2013):

a. laws that can limit weight allowed for a vehicle on certain streets or the length of time that a driver is allowed to drive;

b. the fixing of times of day it can make product delivery or access can be achieved in the areas of delivery. In such cases there is a limitation periods for which a selling point can be supplied, which leads to the need to find alternative delivery routes. In the case of limited delivery periods (for example, delivery is only allowed at certain times or intervals), there are corresponding implications for the quantities of stored goods and replenishment needs;

c. congestion of road traffic within the localities, which causes problems related to the frequency and security of freight deliveries to the points of sale, accordingly increasing the distribution costs;

d. Environmental implications due to reaction pressure groups to the problems caused by car traffic (pollution, increase fuel consumption, noise, visual disturbances etc.).

Among car park management problems can be mentioned:

$\rightarrow$ the structure (composition) of the car park, given the huge variety of vehicles which are available for use in road transport.

The structure of the car park must take into account the nature of the products to be transported, the aids necessary for handling, the use of vehicles etc., all of which entail costs.

There are products such as fragile, frozen or chilled which require specialized transport vehicles and also the commercial establishments (such as supermarkets) that require supplies of products at a variety of temperatures, with vehicles suitable for carrying those products.

A solution to this problem has been to achieve multi-temperature vehicles, which can improve the flexibility of the vehicle, but at a certain cost. Similar difficulties arise in connection with the handling of the products inside and outside the vehicle, with the appropriate use of its space, etc..;

$\rightarrow$ decisions on financing the purchase of vehicles in the car park.

In general, there may be three ways to purchase vehicles namely purchase, leasing and tenancy. The decision on one of these terms and the multiple variants on each item will depend on the specific situation of each operator;

$\rightarrow$ the efficient operation within the car park.

Efficient operation involves operating costs, whose control and measurement raises problems. The strict control and the supervision of the vehicle and driver activity, as well as the compliance with legal requirements are crucial in carrying out any delivery operation (https://www.marketsandmarkets.com/Market-Reports/transportation-management-market $.232446179 . \mathrm{html})$.

\subsection{Practical data}

When people realized how important is aerodynamics in road transport they began to do experiments to determine profitability necessary changes.

For example, vehicles with the same engine Ford and Dubonnet with about equal weight (1400 kg and $1380 \mathrm{~kg}$ ) were tested together, but to bodies of different shapes: Ford had a regular body with rounded corners, and on the Dubonnet car was installed the spray-like body 
(the motor is located in the back). Fuel consumption for the first car was $15.51 / 100 \mathrm{~km}$, and for the second - only $10.81 / 100 \mathrm{~km}$.

From the above data we can be concluded that due to the streamlined body, the car Dubonnet consumed approximately 30\% less fuel (https://ustroistvoavtomobilya.ru/teoriya/soprotivlenie-vozduha-i-rashod-topliva).

As a result of experiments to improve the flow of trucks, it has been shown that an open platform top and sides of a truck chassis unprotected increase air resistance and fuel consumption. However, they can be significantly reduced by simple additions to the truck structure (B Mindrov proposed by N. V. I. and Divakov). So, when installing shields under the side of the body, fuel consumption is reduced by $2.5 \%$, when the body is covered with a dent on the sides - 4-4,5\%. This data refers to motorway travel at $50-60 \mathrm{~km} / \mathrm{h}$ speed. These data relate to highway cruising at a speed of 50-60 km/hour. Even better results can be obtained by providing simultaneously a form more streamlined cab and rear end of the truck, but this is due to change the entire structure of these elements (https://ustroistvo-avtomobilya.ru/teoriya/soprotivlenievozduha-i-rashod-topliva).

Fig. 3. CX coefficient for different types of cars.[According to $5^{\text {th }}$ source ]

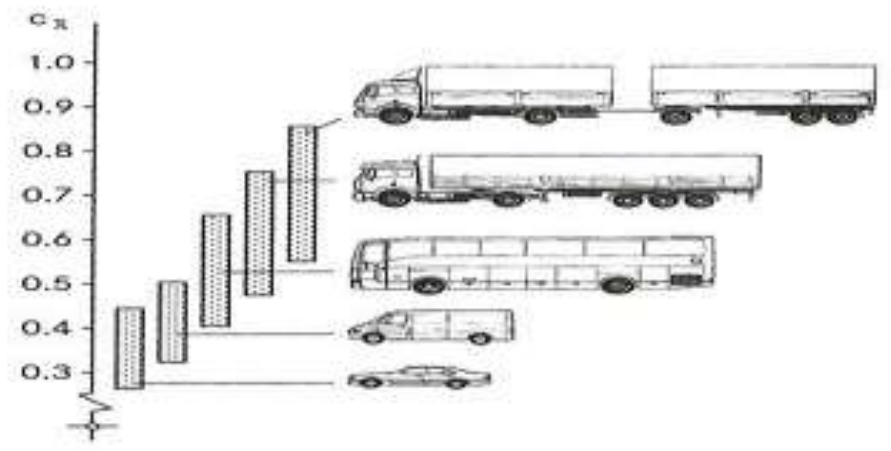

\section{Source: https://glonassgps.com/aerodinamika-i-rashod-topliva}

While car manufacturers have several maneuvers to streamline the body, in the case of trucks and buses it is more difficult.

Their shape should be close to the rectangle for optimum load and passengers placement while maintaining the minimum area. And features such as a large cross-section and angular contours increase at last the $\mathrm{Cx}$ coefficient.

Fig. 4. CX aerodynamic coefficient influence under the fuel consumption trucks.

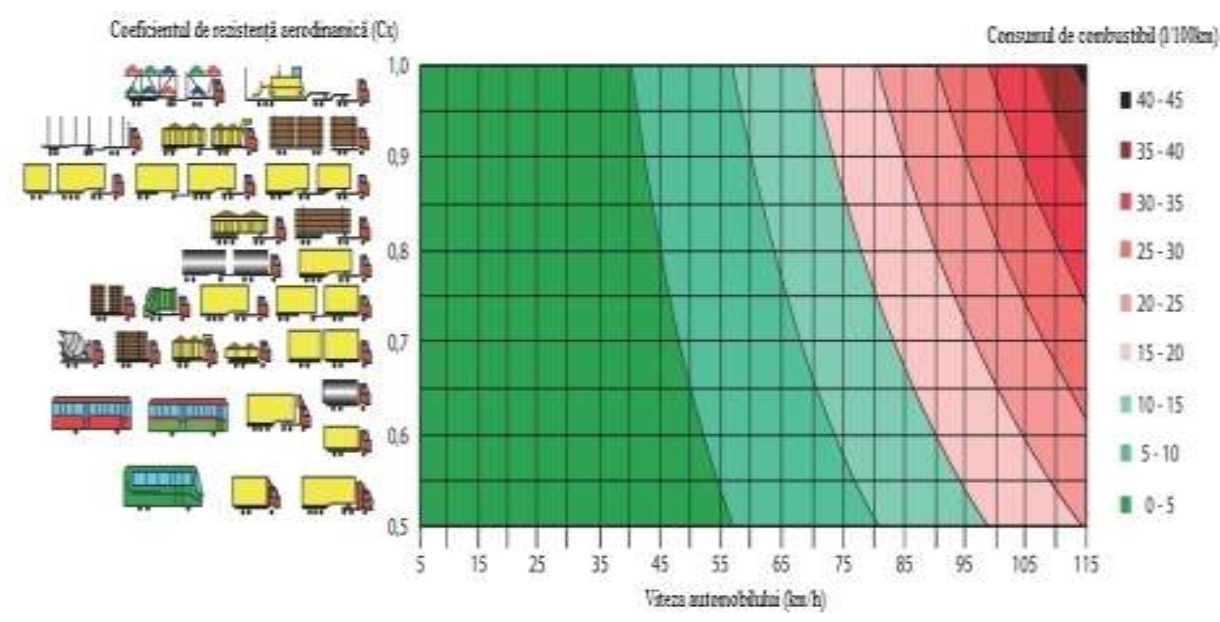

Source: https://glonassgps.com/aerodinamika-i-rashod-topliva 
For example, in the case of heavy trucks, turbulence gives high fuel consumption resulting from the fact that the height of the trailer is often lifted above the cab. Also, the force of air resistance increases due to a large clearance. The role is played by the empty space between the car and trailer, the trailer and the semi-trailer. The higher is the vehicle speed, the more fuel will be consumed (fig.4).

The improvement of the aerodynamic quality of the lorries and fuel saving enables various components of the aerodynamic body kit to be used as shown fig. 5 . These are the upper cab blocks, the rear cellars, the bumper journals, front sun visors, corner deflectors and a number of other devices.

Fig. 5. Optimisation of the aerodynamic CX coefficient by means of various additional elements

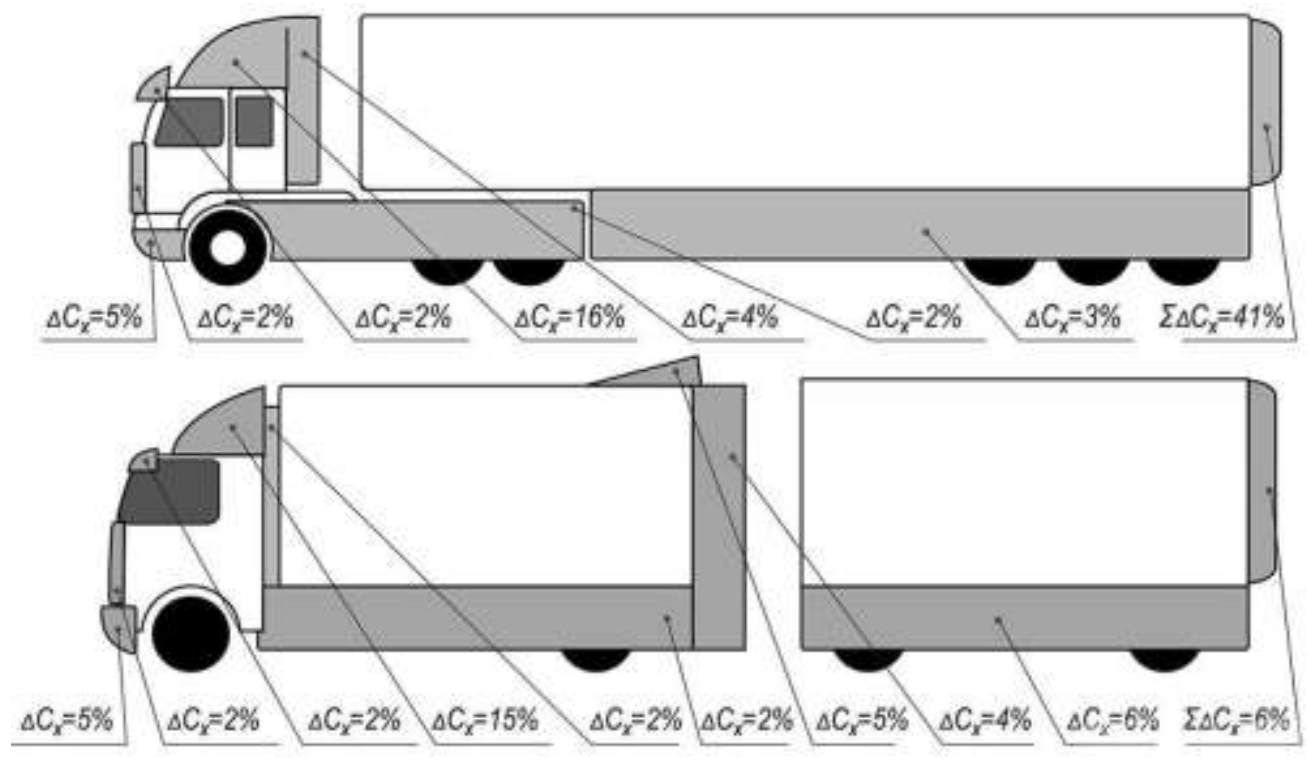

Source: https://glonassgps.com/aerodinamika-i-rashod-topliva

1. According to "Gruzovik Press" study, the KAMAZ-4325 without cowling at an average

speed of $90 \mathrm{~km} / \mathrm{h}$ consumes 28.3 litters of fuel $/ 100 \mathrm{~km}$. With the installation of cowling, the flow will be $26.91 / 100 \mathrm{~km}$. Thus, under real conditions must considering the acceleration and deceleration - saving is 1.4 -liter or $4.9 \%$ (https://glonassgps.com/aerodinamika-i-rashod-topliva ) .

2. And the ling tests of the GAZ-17310 "TROFIM" have confirmed that in constant speed mode (from 40 to $70 \mathrm{~km} / \mathrm{h}$ ) savings range from 0,2 to $0,8 \mathrm{l} / 100 \mathrm{~km}(3,0 \%$ and $9 \%$ and 1 $\%$ respectively). The maximum speed of the cowling is $120.5 \mathrm{~km} / \mathrm{h}$, without the cowling - 111.3 $\mathrm{km} / \mathrm{h}$. The difference is $7.6 \%$ (https://glonassgps.com/aerodinamika-i-rashod-topliva).

3. Another illustrative example is the MAZ-5432 car with a maximum weight of 32 tons, which was fully equipped with aerodynamic body elements.Due to the $39 \%$ decrease in the $\mathrm{Cx}$ coefficient, the maximum speed increased by $8 \%$ and the productivity (average technical speed and load capacity) increased by $5 \%$.( https://glonassgps.com/aerodinamika-i-rashod-topliva ).

The other way to save the road transport costs is to create car columns.

In this direction research is done by a number of companies and start-ups from different countries, over a long time period.

Theoretically, this is easily achievable: a truck follows another only a short distance (about $10 \mathrm{~m}$ ). Due to the low pressure area, relative to atmospheric, that is created from the first truck, the other front truck encounters air resistance lower than the first (fig. 6).

Such start-up, such as Peloton technology, is dealing with the creation of intelligent auto columns within 8 years: two trucks already are sufficient to create self this intuitive auto column, 
and here it works: each of the vehicles are equipped with an auxiliary system that can intervene in the management of transport with some manoeuvres (sudden braking).

Fig. 6. Air flow surrounding the truck

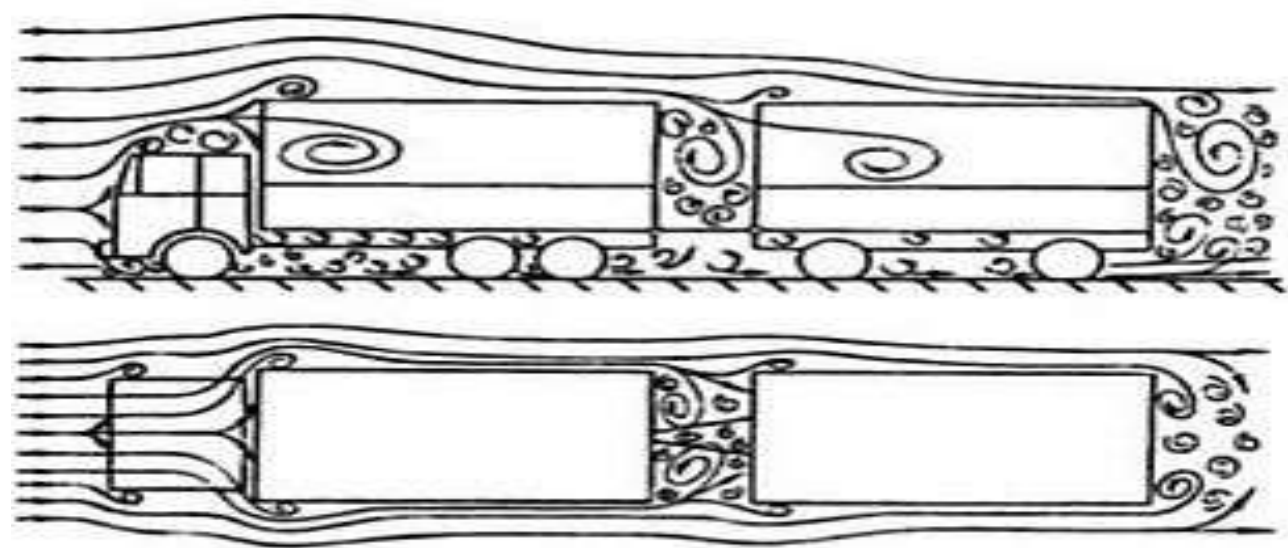

Source: https://peloton-tech.com/

At the same time, this system links the trucks with a local Wi-Fi network but has a higher signal transmission speed. Once the vehicles have been connected, both drivers have to press a button so the rear lorry starts tracking the column leader automatically.

To disconnect the vehicles apart to perform the same action, ie: both drivers must press a button intended for this action.

Due to the implementation of such a system those who developed it forecast fuel savings of up to $50 \%$, or $\$ 300$ billion USD by 2032 [According to $7^{\text {th }}$ source].

During the existence of this project, star-up has found several clients to implement the given system, whose names are not publicized, because there is still no country with a draft law that could regulate such a system. So basically, at the moment, this system is illegal.

\section{Conclusions}

Trucks carry some $80 \%$ of all cargo on land routes in the world (IRU, 2005) and the heavy road transport has a special importance in economic development and the delivery of the good quality services is key to successful operations, and its importance is growing.

Transport costs reduction can be achieved in two ways:

$\rightarrow$ constructive modification of vehicles in order to reduce air and fuel consumption respectively;

$\rightarrow$ by logistics through the organization of fairs (car trains) in order to reduce the resistance costs of the goods transport by the integrating of marketing vision within the organisation

\section{References}

1. Constantinescu, L. M. (2007), Total quality - a new paradigm in quality management, Quality - Acces to Succes, no. 7-8 available on https:// wmw.srac.ro/ calitatea/ en/arbiva/2007/07_08_2007.pdf

2. Dantuma, L. M. Y. \& Hawkins, R.W. (2001), E-commerce in the logistic sector. Assessing the effects on the logistic value chain, TNO Strategy, Technology and Policy available on bttp:// wnw. oecd.org/sti/ieconomy/2072925.pdf

3. Gattorna, J. L. (1999) The Gower Handbook of Logistics and Distribution Management-4 ${ }^{\text {th }}$ edition, Teora Publishing, Bucharest.

4. Caraiani, G., Potecea, V. (2013), LOGISTICA in afacerile internaţionale, Editura Universitarằ Publishing, Bucharest. 
International Conference "Risk in Contemporary Economy" ISSN-L 2067-0532 ISSN online 2344-5386

$\mathrm{XX}^{\text {th }}$ Edition, 2019, Galati, Romania,

"Dunarea de Jos" University of Galati, Romania - Faculty of Economics and Business Administration

5. Information on the contribution of land transport to logistics available on bttps:/ / wmw.marketsandmarkets.com/Market-Reports/transportation-management-market 232446179.html open on 28.03.2019.

6. Information on improving the aerodynamics of the truck available on https://glonassgps.com/aerodinamika-irashod-topliva open on 29.03.2019.

7. Information on conducted experiments available on https:// ustroistvo-avtomobilya.ru/teoriya/soprotivlenievozduha-i-rashod-toplival open on 29.03.2019.

8. Information about car trains available on https://peloton-tech.com/ open 30.03.2019.

9. International Road Transport Urban (IRU), Trade impossible without road transport, Geneva 4 November 2005 available on https://www.iru.org/sites/default/files/2016-01/en-iru-trade-road-transports-wto2005.pdf open on 30 May 2019.

10. International for Reconstruction and Development/The World Bank (2018), Connecting to Compete 2018. Trade Logistics in the Global Economy available on www.worldbank.org accessed on 30.05.2019 